\title{
Developing and implementing communications strategies: A descriptive model
}

\author{
Loma A. Hill and A.A. Archer* \\ University of Stellenbosch Business School, P.O. Box 610, Bellville, 7535 Republic of South Africa
}

Received 2 July 1987

\begin{abstract}
The world-wide environment. but particularly the South African environment today has created a growing need for businesses to communicate effectively with their stakeholders. The number of stakeholders interacting with companies has burgeoned. their demands have become greater and the need for change is critical. As these pressures increase. the need for companies to communicate effectively will grow. In South Africa the pussibility for misunderstanding is compounded by communication barriers such as the socio-political system. diversity of cultures and languages. as well as the many different levels of education. In an environment such as this the need for effective communication is so great that a company can clearly no longer rely on ad hoc, reactive communications to facilitate the achievement of corporate goals. In order to ensure effective communication a company needs to have an overall communications strategy which has its roots in corporate goals and strategies. Developing and implementing communications strategies involves many complex considerations such as the identification and analysis of stakeholders and their power bases, issues management. corporate image and culture. crisis communications planning. media planning and dealing with communication barriers. This article provides a suggested framework for integrating these and other considerations into the development and implementation of communications strategies.
\end{abstract}

\begin{abstract}
Die wèrelduve omgewing. maar veral die omgewing in Suid-Afrika vandag het 'n groeiende behoefte geskep vir ondernemings om doeltreffend met hul belangegroepe te kommunikeer. Die behoefte vir verandering is noodsaaklik en ondernemings bevind hulself in wisselwerking met ' $n$ toenemende aantal belangegroepe wat al hoe groter eise aan hulle stel. Soos hierdie druk toeneem. sal die behoefte vir ondernemings om doeltreffend te kommunikeer groei. In Suid-Afrika word die moontlikheid van misverstand deur kommunikasiehindernisse soos die volgende vergroot: die sosio-politieke stelsel. verskeidenheid van kulturgroepe en tale asook die verskillende vlakke van opvoeding. In $n$ omgewing soos hierdie is die behocfte aan doeltreffende kommunikasie so groot dat $n$ onderneming duidelik nie meer op ad hoc. reaktiewe kommunikasic kan staatmaak om die bereiking van maatskappydoelstellings te vergemaklik nic. Om doeltreffende kommunikasie te verseker. moet in onderneming 'n algemene kommunikasiestrategie hê met maatskappydoelstellings en -strategieë as grondslag. Die ontuikkeling en implementering van kommunikasiestrategieë behels baie ingewikkelde oorwegings soos die identifisering en ontleding van belangegroepe en hul magsbasisse. hantering van vraagpunte. maatskappybeeld en -kultuur, beplanning van krisiskommunikasie, mediabeplanning en die hantering van kommunikasiehindernisse. Hierdie artikel. bied 'n voorgestelde raamwerk om hierdie en ander orwegings te integreer in die ontwikkeling en implementering van kommunikasiestrategieë.
\end{abstract}

- To whom correspondence should be addressed

\section{Introduction}

The human climate has become a determining factor in the future of all organizations. Businesses are having to deal to an increasing degree with stakeholder perceptions. This trend has magnified the role of communication in business enterprises. As the pressure from stakeholders increases, effective communication will become increasingly necessary for the survival and success of a business. While this is true world-wide, it is particularly pertinent in the rapidly changing South African environment of today. Little conceptual discussion or empirical research has, however, been done in South Africa on this topic.

This article presents a descriptive model for developing and implementing communications strategies.

The three-fold purpose of the model presented in this article is

- provide management with guidelines for using communication to facilitate the achievement of corporate goals and gain a competitive advantage;

- promote strategic thinking in the field of communication;

- indicate how stakeholder information can be integrated into communications strategies.

\section{The need for communications strategies}

The environment in South Africa today has created a growing need for businesses to communicate effectively with their publics.

The number of publics or stakeholders interacting with companies has burgeoned and their relative power and sophistication have increased dramatically. Business is having to deal to an increasing degree with issues such as black resistance to the free enterprise ethic, militance in labour relations, disinvestment, sanctions and organized consumerism and environmentalism. Business success depends to a great extent on whether stakeholders can be persuaded to support corporate goals rather than obstruct or actively oppose them. Communication can therefore play an important role in facilitating the achievement of corporate goals.

Furthermore, the demands made by these various groups upon the business are many and varied, including the request to assist with social problems such as education, housing, urban renewal and development, and equal opportunity. This social role of business is closely linked with its economic mission. The more aware a company is of social forces and the more it uses its influence to push for positive change, the better the 
general business climate will be in the long run

The demands by stakeholders for business to play an active role in initiating social and political change in South Africa have never been greater. Communication is the lubricant that can make it possible for these changes to take place in an atmosphere of understanding. If these non-commercial areas of business communication, i.e. communication activity not directly related to promoting the sale of a company's products or services, are neglected society will tend to react. And if the reaction is one of protest it can be seriously disruptive to the income-generating ability of a company.

Communicating effectively with stakeholders is a problem world-wide, but in South Africa the situation is compounded by barriers such as the socio-political system, diversity of cultures and languages, as well as the many different levels of education and cultural development. These barriers increase the possiblity for misunderstanding and conflict.

The Human Sciences Research Council reported in its Investigation into Intergroup Relations (1985) that ineffective communication and often even a total lack of communication was one of the major factors causing conflict to escalate into violence in South Africa.

In an environment such as this, the need for effective communication has become so great that a company can clearly no longer rely on ad hoc communications with its various stakeholders on issues affecting business. In order to ensure effective communication a company needs to have an overall communications strategy that organizes and coordinates what, when, how, and if the company communicates. These are important business decisions which necessarily tie communication with strategic management. Effective communication should have its roots in corporate goals, objectives and strategies.

Reactive communication is less effective than communication that is used as a strategic tool. When a business anticipates events and communicates with its stakeholders before a crisis arises, it will have more control over its communications than when it uses communication to react under pressure, i.e. as a tactical weapon.

Effective communication is necessarily a two-way street. It involves listening, seeing and observing as well as transmitting information. The failure of a business to understand the nature of the human climate in which it operates will create a situation in which much of what it communicates is irrelevant or unintelligible to the target audiences concerned. The relative deafness and blindness of a business also means that it is out of touch with social and political realities. Scanning the stakeholder environment is therefore an important phase in the development of communications strategies.

\section{Advantages of communications strategies}

An overall communications strategy can work for a company in many ways.
Image

A positive image is important in recruiting employees, cultivating employee commitment and morale and achieving success in the marketplace.

Many different messages that in sum result in the corporate image are communicated through many sources and channels. A business communicates directly and indirectly with its stakeholders on various issues. Direct (verbal) communication includes advertising, promotion campaigns, speeches, press releases, annual reports, meetings, etc. A business also, however, communicates indirectly (non-verbally) through its actions. An overall communications strategy enables the various departments of a company to develop a cohesive position and speak with one voice to its many audiences on issues that are dealt with publicly. It also ensures that communications accurately reflect corporate actions and achievements.

Unless there is an overall communications strategy, it is likely that some of the messages (verbal and nonverbal) will not reinforce one another and others may be contradictory. All of this can result in a blurred or negative image which can seriously undermine the credibility of the company. For instance, if a company claims to have the interests of the community at heart in its social advertising campaign, but is guilty of polluting the environment, its credibility will be jeapordized. Communicated reputation should not be a fabricated facade or superficial image.

It is therefore essential that the verbal and non-verbal messages emanating from the business be carefully coordinated into an overall communications strategy.

\section{Identity}

An overall communications strategy helps to give a company a clear and distinctive identity. This is a source and means of competitive differentiation in strategy development. Identity is also the source of corporate culture. Peters \& Waterman (1982) identified a distinct corporate culture as one of the features that successful companies have in common.

\section{Stakeholders}

An important phase in the development of communications strategies is the identification of stakeholders. This enables the company to identify those audiences that may be important to its business in the future. By regularly monitoring the opinion of stakeholders the company will be alerted to emerging issues and therefore be in a position to respond to those issues that may affect it and to develop timely and effective strategies before the problems become crises.

\section{Communications network}

For those crises that do occur, the company will have an organized communications network of people who are familiar with the process of developing communications strategies and who are ready to respond as a team. 


\section{The model}

The various components of the model depicted in Figure 1 will now be discussed.

\section{Identifying stakeholders}

The first step in developing communications strategies is identifying the potential audiences with whom the company may need to communicate. This will include all individuals and groups who influence or may be influenced by the actions of the business, i.e. the stakeholders.

The extent to which a company is able to meet the demands of stakeholders is termed effectiveness. Hofer \& Schendel (1978:2) define effectiveness as the ratio of outputs produced by an organization to the societal outputs desired from the organization. Clearly the societal outputs desired from the organization can only be judged by those groups or individuals who come into contact with it, i.e. the company's stakeholders. The typical stakeholders of a company are the shareholders, employees, customers, suppliers, government, the general public, the financial community and the media. Stakeholders are therefore the judges of organizational effectiveness. In order to be effective a company first has to know who will be judging its effectiveness. In other words, stakeholders must be identified.

Given that management has a clear understanding of corporate goals, objectives, strategies and their scope, identifying the individuals and groups with which a company should communicate is largely a question of determining who is in a position to significantly help or hinder the achievement of those goals - in the long as well as in the short term.

\section{Stakeholder analysis}

The second step in the development of communications strategies requires an analysis of the stakeholder

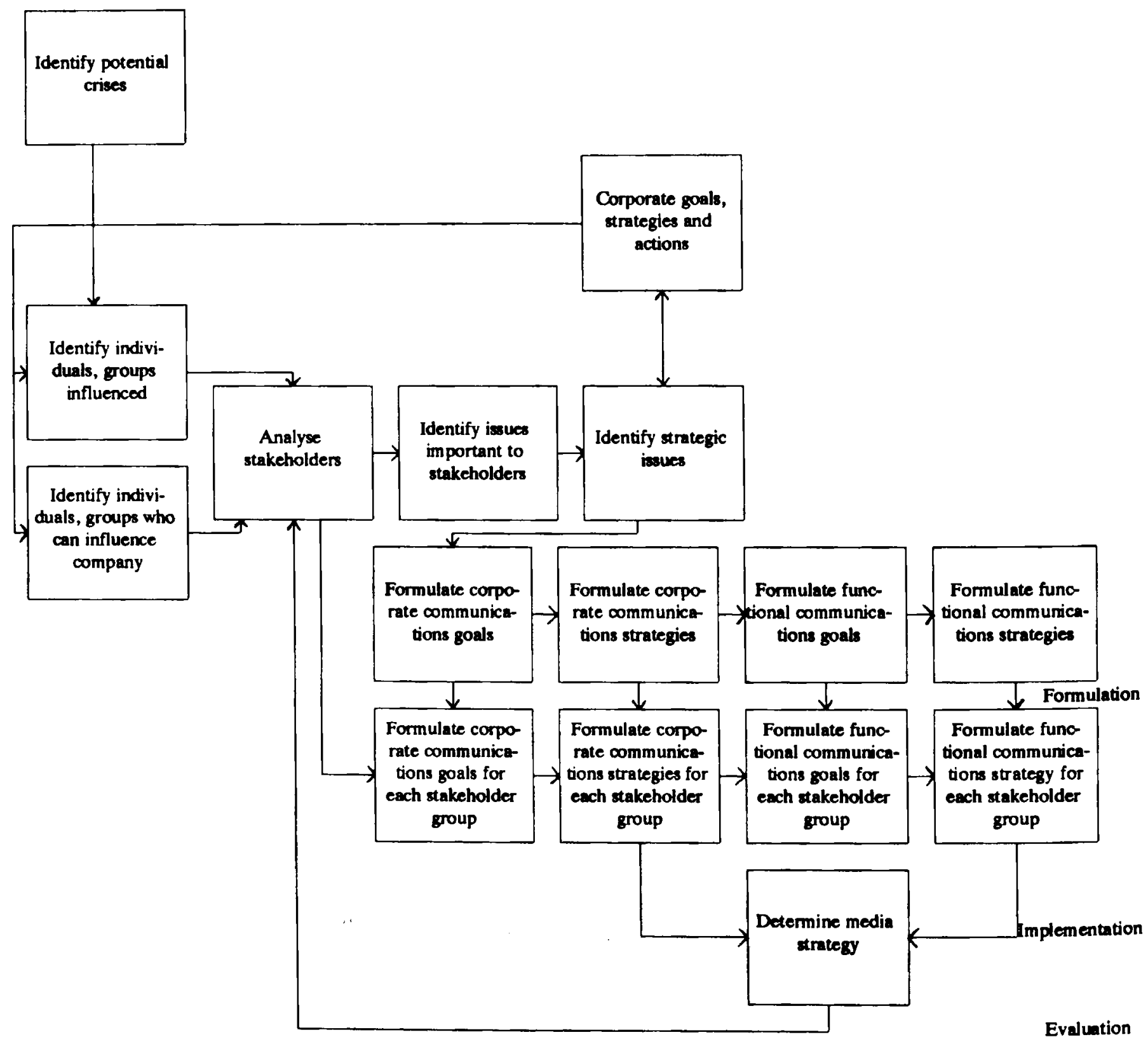

Figure 1 Model of communications strategies 
environment or human climate within which the business operates.

The consequences of environmental threats and opportunities are largely determined not by a situation per se, but by how people perceive a situation and how they respond to it. Although managers are continually being confronted by issues such as boycotts, product safety, personnel recruitment, retrenchment and productivity, many of these are problems of human attitude rather than material, tangible practicalities. The fact is that all major strategic decisions have implications for stakeholders. The bigger the decision, the larger the company and the greater the number of stakeholders that are affected, the more significant the communications component becomes.

In formulating communications strategies, stakeholder analysis helps management to understand its audiences and to consider how they will interpret company communications. Without such analysis communications decisions will be made in a vacuum; the message may not be relevant to the interests of the stakeholders, it may not reach them or it may be misinterpreted by them.

Stakeholders should be analysed on an on-going basis and not only when problems occur. A company should not wait until the opinions of stakeholders are suddenly crucial before undertaking attitude research. It may then be too late. Regular attitude research enables a company to detect potential threats before they become crises. The company can then engage in opinion-forming communications to prevent the crisis from occurring.

Formal stakeholder analysis takes the formulation of communications strategies out of the realms of assumptions and guesswork and provides results which serve as a benchmark for evaluating the effectiveness of communications strategies. It provides management with a more tangible form of data. This data will have to be gathered from a wide variety of sources - from management, independent appraisers and the stakeholders themselves.

Stakeholders should not be regarded as one homogenous mass. Stakeholder analysis will reveal that they differ in terms of the issues which are important to them and how they interpret what the company communicates.

In order to better understand stakeholders they should be analysed according to the following dimensions:

- Opinions and attitudes. By regularly measuring the attitudes, perceptions and opinions of stakeholders, issues important to them and to the company can be identified. If the company decides to speak out on these issues, they will form the content of the company's communications. It is important that messages transmitted by a company have relevance for the audience at which they are aimed.

- Social values. Social values influence the attitudes and opinions of people. They direct people to selectively attend to some goals and to subordinate others. It is therefore worth the trouble to investigate whether the pcople with whom the company deals have different priorities. Messages transmitted by a company must be compatible with stakeholders' value systems.

- Cultural factors, for example cultural composition, behaviour patterns, habits, language, etc. An awareness of the relationship between culture and communication as well as an understanding of the differences between cultures is helpful - and at times essential - in communicating successfully, especially in the multicultural South African environment. Lack of intercultural communication skills is probably one of the major reasons for ineffective communication between South African businesses and their stakeholders. In our complex cultural environment it is essential that cultural sensitivity and empathy be cultivated. Culture comprises many elements: language, semantics, religion, values and attitudes towards time, achievement, wealth, change and private enterprise all influence how a company's general actions and communication efforts are interpreted. Every time one of these cultural barriers must be crossed there is a potential communication problem.

- Micropolitical environment of the stakeholder group, for example how decisions are made, the basis and location of power. Macmillan (1978) identifies the following sources of power:

(i) Possession of resources. This power arises from the fact that the stakeholders may refrain from supplying the company with much needed resources. Skilled workers who resort to strike action are in a powerful position to assert their demands for pay increases if the company cannot employ replacement workers

(ii) Dictation of alternatives (substitutes). A sole supplier, for example, only has a strong power base as long as no substitute materials exist.

(iii) Authority. Authority is the right to enforce obedience. The power bases of government and regulatory bodies are derived from authority.

(iv) Influence. An ecological body could for instance influence politicians to use their power, rooted in authority, to pass anti-polution legislation.

- Goals, objectives and strategies of stakeholder groups. Some stakeholder groups are so amorphous that they do not have cohesive group goals or strategies. Where group goals can be identified it is useful to analyse them in terms of (1) what the stakeholder group is trying to accomplish in the long term, (2) what the stakeholder group is trying to accomplish as regards a certain issue, and (3) what the linkage is between a certain issue and the stakeholder's long-term goals.

- Company information required by stakeholders. What do stakeholders want to know about the company? What information is relevant to their needs? What are their horizons of interests? This information is important for determining the content of corporate communications.

Once stakeholders have been analysed in terms of these dimensions, they must be ranked according to their potential impact on the company. Given unlimited communication resources, the audiences with whom a company could profitably communicate is extensive. A 
Table 1 Impact of stakeholders on company success

\begin{tabular}{|c|c|c|c|c|c|}
\hline & \multicolumn{2}{|r|}{ Very } & portant & \multicolumn{2}{|c|}{$\begin{array}{c}\text { Not } \\
\text { Helpful applicable }\end{array}$} \\
\hline Shareholders & & & 3 & 1,2 & \\
\hline Employees & 1,2 & & & & \\
\hline Customers & $1,2,3$ & & & & \\
\hline Suppliers & 3 & 2 & 1 & & \\
\hline Government & 3 & 2 & 1 & & \\
\hline General public & & 2,3 & 1 & & \\
\hline Financial community & & & 1,2 & & \\
\hline Media & & & 1,2 & & \\
\hline Trade unions & & $1,2,3$ & & & \\
\hline
\end{tabular}

1 = Achievement of corporate goals (objectives) in the short term

2 = Achievement of corporate goals (objectives) over the next five to ten years

$3=$ The climate of opinion towards private enterprise

company's resources are, however, finite and management must establish priorities in terms of those with which it will communicate. This information can be displayed in grid form. Table 1 is an example of how this grid may look.

Essential stakeholders of the company, i.e. groups or individuals who are irreplacable, should receive special attention. These include sole suppliers of goods or services for which there are no substitutes, key employees and major customers.

A company should also pay particular attention to stakeholders who occupy judicial positions, for example government departments and regulatory bodies. Failure to do this may result in legislative action.

It is also important to identify special interest groups such as environmentalists and consumer associations who have a high degree of exposure and are capable of imposing legislation via government departments.

This allocation of priorities will be influenced by the kind of business a company is in. For example, a manufacturer of stoves, refrigerators and television sets will have consumer protection groups high on his priority list, while environmental protection groups will be high on the list of a manufacturer of chemicals or fertilizers.

Stakeholder analysis may also reveal a communication gap between a company and an important stakeholder group which would indicate that this group should receive special attention.

\section{Identifying issues important to stakeholders}

The monitoring of stakeholders described in the previous section is likely to reveal a number of emerging issues which could impact on the company. These issues will relate to such aspects as profits, product safety, service, truth in advertising and promotion.

A list of key concerns or issues must be developed for each stakeholder group. This information can be displayed in a matrix of stakeholders versus issues. Table 2 is an example of how this matrix may look. The sooner a company can detect an issue that is important to
Table 2 Stakeholders/issues matrix

\begin{tabular}{|c|c|c|c|c|c|c|c|}
\hline & 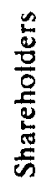 & 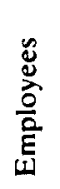 & 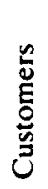 & 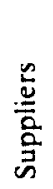 & 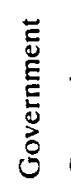 & 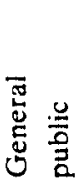 & 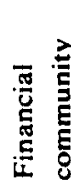 \\
\hline Financial returns & 1 & 2 & 3 & 3 & 3 & 3 & 1 \\
\hline Truth in advertising & 3 & 2 & 1 & 2 & 2 & 2 & 3 \\
\hline \multicolumn{8}{|l|}{ Environmental pollu- } \\
\hline tion & 2 & 2 & 2 & 3 & 1 & 1 & 3 \\
\hline Product service & 3 & 2 & 2 & 3 & 3 & 1 & 3 \\
\hline Remuneration & 2 & 1 & 3 & 3 & 2 & 2 & 3 \\
\hline Creation of jobs & 3 & 1 & 3 & 3 & 1 & 2 & 3 \\
\hline
\end{tabular}

1 = Critically important to stakeholders; 2 = Important to stakeholders; 3 = Unimportartant to stakeholders

stakeholders, the more choices it has in responding to the issue and the greater probability it has of influencing the outcome of the issue in its favour by means of opinion-forming communication.

\section{Identifying strategic issues}

Once issues that are important to stakeholders have been detected, they must be evaluated in terms of the following dimensions in order to prioritize them:

- Impact on the company and industry in the short term and the long term

- Probability of occurrence

- Probable time of impact

- Probable behaviour of stakeholders

The purpose of this exercise is to narrow down the number of issues so that the company can concentrate its communications effort on those issues which, if handled correctly, can enhance the achievement of the company's strategic objectives.

These so-called strategic issues are forthcoming developments, either inside or outside the company, which are likely to have an important impact on the ability of the enterprise to meet its objectives. A strategic issue may be a welcome issue, i.e. an opportunity to be grasped in the environment or an internal strength which can be exploited to advantage. It can also be an unwelcome external threat, or an internal weakness which imperils continuing success, and even the survival of the enterprise (Ansoff, 1980:133).

Corporate goals, objectives and strategies clearly play a major role in the establishment of strategic issues. An effective linkage between communications on these issues and strategic planning is essential to both the success of broader corporate strategies and communications strategies. Strategic issues should be an integral part of the process of developing communications strategies to ensure that stakeholder issues are adequately addressed and that the achievement of strategic goals is not jeapordized by any form of social censure.

A scheme which can aid in the identification of 
Table 3 Probability/Impact grid

\begin{tabular}{lllll}
\hline & \multicolumn{3}{c}{ Probability of occurrence } \\
\cline { 2 - 5 } Impact & High & & Medium & Low \\
\hline High & Issue & Issue & Issue & Issue \\
& Issue & Issue & Issue & Issue \\
& Issue & Issue & Issue & \\
Medium & Issue & Issue & Issue & \\
& Issue & Issue & Issue & \\
Low & Issue & Issue & & \\
& Issue & Issue & & \\
& Issue & Issue & & \\
& Issue & & & \\
\end{tabular}

strategic issues is the probability/impact grid (Johnson, 1983:26). The grid, illustrated in Table 3, evaluates issues which could have a significant impact on the company according to the probability of occurrence and level of impact. The high probability/high impact issues are the strategic issues which should be given top priority in the development of communications strategies.

Once strategic issues have been identified the company must decide on which of these it needs to communicate with stakeholders. This decision is based on a number of important considerations:

- What are the pros and cons of speaking out on a certain issue?

- Do the actions and strategy of the company support what it has to say publicly

- What are the long-term implications of speaking out publicly?

- How will the company respond if it decides not to speak out publicly?

A company cannot afford to speak out on too many issues. Its expertise and resources would not be sufficient.

It may be unwise for a company to take a public stand on issues that are very controversial or volatile and pose a no-win situation. A company, however, communicates by default just as surely as by design, and if left to chance the wrong message may get across to stakeholders.

A company should also avoid being over-selective in the information it divulges. The credibility of the company will be enhanced if it has the reputation of giving a complete account in both good times and bad, i.e. if it has an open communications climate with stakeholders

\section{Identifying potential crises}

Crises, by definition, cannot be planned. However, a company can plan its response to a crisis. The consequences of not planning crisis communications can be damaging to all aspects of a company. Many companies have had to contend with image problems years after a crisis, simply because of their lack of crisis communications planning.

A coherent approach to crisis communications strategy begins with identifying potential crises. These would include existing situations or problems which have the potential to develop into crises; previous crises that may recur; and crises that have beset similar companies.

Once potential crises have been identified, the next step is to determine who the target audiences of crisis communications will be. This will include employees who are directly involved in handling the crisis, employees who are affected by it, as well as external stakeholders who may be directly or indirectly affected by the crisis. The potential reactions of these stakeholders should receive attention during stakeholder analysis.

\section{Formulation}

Once management has decided on which strategic issues it needs to communicate with stakeholders, specific communications goals and stategies must be formulated. This provides the framework for all corporate communications. Communications goals and strategies can be formulated at three levels, namely corporate, functional and stakeholder. Communications strategies should be consistent with each other and with the overall corporate strategy in order to enhance credibility.

Communications goals must be written, realistic, measurable and set in a time frame so that progress can be monitored and evaluated.

\section{Implementation}

Once the communications components of strategic issues have been formalized into communications goals and strategies, management must decide how to put these strategies into practice.

An important aspect of implementing communications strategies is deciding on what mix of communication techniques and media to use. Factors such as the size, diversity and nature of the target audience, the message to be communicated and the funds available play a role in this regard. Although the media decisions are usually left to communications specialists, management should be aware of the relative strengths and weaknesses of the media available.

\section{Evaluation}

This is the final phase of the model. Periodic evaluation of communications strategies is essential as no communications strategy is permanent. As a company's strategies change and as the internal and external stakeholder environments change. so may the communications goals, objectives and strategies. It is possible that the communications strategies may remain the same, but that the communication media may need to change.

Research should be carried out at given intervals and measured against the benchmark research done prior to implementing the communications strategy in order to monitor the success of the strategy in terms of the communications goals. At these evaluation points new knowledge or information may shape new goals or reconfirm the original strategy. 


\section{Conclusion}

The need for effective communication in the complex rapidly changing South African environment of today is great, and will increase as stakeholder pressure increases. Unless a company communicates effectively with its stakeholders, its success will be seriously jeapordized in the future.

Effective communication is, however, not easy to achieve - it involves many complex considerations. The framework suggested in this article is an attempt to integrate these considerations into a model for developing and implementing communications strategies.

\section{References}

Ansoff. H.I. 1980. Strategic issue management. Strat. Manage. J., vol. 1, 131-148.

Hofer, C.W. \& Schendel, D. 1978. Strategy formulation: analytical concepts. St. Paul: West, 219p.

Human Sciences Research Council. 1985. Investigation into Intergroup Relations. Pretoria: Human Sciences Research Council, 182p.

Johnson, J. 1983. Issue management - what are the issues? Bus. Quart., vol. 48, no. 3, 22-31.

Macmillan, I.C. 1978. Strategy formulation: political concepts. St. Paul: West, $167 \mathrm{p}$.

Peters, T.J. \& Waterman, R.H. 1982. In search of excellence. New York: Harper \& Row, 360p. 